\title{
Investigation of the embryotoxic and teratogenic effect of Hypericum perforatum in pregnant rats
}

\section{Hypericum perforatum'un gebe sıçanlarda embriyotoksik ve teratojenik etkisinin araştırilması}

\author{
(D) Fadime Kahyaoğlu1, (D) Alpaslan Gökçimen², (D) Buket Demirci3 \\ ${ }_{1}$ Avrasya University Vocational School of Health Services, Department of Pathology Laboratory Techniques, Trabzon, Turkey \\ 2 Adnan Menderes University Faculty of Medicine, Department of Histology and Embryology, Aydin, Turkey \\ 3 Adnan Menderes University Faculty of Medicine, Department of Medical Pharmacology, Aydin, Turkey
}

\begin{abstract}
Objective: Hypericum perforatum (HP) is a herbal product used in the treatment of depression, but its harm on the fetus has not been established. This study investigated the effects of HP according to fetal clinical, morphologic, and histologic findings. Study design is an animal study. Materials and Methods: Fifty-four 4-5-month-old female Wistar rats were divided into three groups: control, $100 \mathrm{mg} / \mathrm{kg}$ HP, and $300 \mathrm{mg} / \mathrm{kg}$ HP. HP treatment using drinking water was started one week before mating and ended with the delivery of pups. Results: HP exposure before conception diminished the pregnancy rate and decreased the fetal number; during pregnancy it tended to increase the duration of gestation, and deteriorated the fetal development as determined using body weight. It also damaged liver and kidney tissues, most probably due to oxidative stress, as supported through inducible nitric oxide synthase antibody staining findings at both doses. Conclusion: HP should not be recommended to women who would like to be pregnant or are pregnant because it can be harmful for both fetal and maternal health.
\end{abstract}

Keywords: Pregnancy, rat, St. Johns Worth, teratogenity

$\ddot{O} z$

Amaç: Hypericum perforatum (HP) depresyon tedavisinde kullanılan bitkisel bir üründür, fakat fetüs üzerindeki zararı henüz tam belirlenememiştir. $\mathrm{Bu}$ çalışma fetüsun klinik, morfolojik ve histolojik bulgulara göre HP’nin etkilerini araştırmayı amaçlar. Çalışma tasarımı, hayvan araştırmasıdır. Gereç ve Yöntem: Dört-beş aylık dişi 54 Wistar sıçan üç gruba ayrıldı: Kontrol, 100 mg/kg HP ve 300 mg/kg HP grupları. HP tedavisi çiftleştirmeden bir hafta önce başlayıp, yavruların doğumu ile sona erdi; içme suyu ile verildi.

Bulgular: Konsepsiyon öncesi HP maruziyeti gebelik oranını düşürdü ve fetüs sayısını azalttı gebelik sırasında gebelik süresini uzatma eğilimindeydi ve vücut ağırlı̆̆ından belirlediğimiz üzere fetal gelişimi bozdu. Hatta, indüklenebilir nitrik oksit sentazi antikor boyaması ile bu çalışmamızı desteklediğimiz üzere, her iki dozda da, büyük olasılıkla oksidatif stress nedeniyle karaciğer ve böbrek hasarına yol açtı. Sonuç: HP hamile kalmak isteyen ya da hamile olan hiçbir kadına önerilmemelidir, hem anne hem bebek sağlı̆̆ı üzerinde tehdit edicidir.

Anahtar Kelimeler: Gebelik, sıçan, St. Johns Worth, teratojenite

PRECIS: Considering of required studies about Hypericum perforatum (HP) and fetal exposure, this study has been evaluated adverse effects of HP on fetus both with the clinical findings and histopathological assessment of fetal liver and kidney.

\section{Introduction}

Hypericum perforatum (HP), of the Clusiaceae (Hypericeae $=$ Guttiferae) family, belongs to the subfamily Hypericoideae $^{(1-4)}$. HP contains several groups of components that contribute to its pharmacologic activity. These are naphthodianthrones (hypericin, pseudohypercin), phloroglucinols (hyperforin, adipherforin), flavonoids (rutin, hyperoside, quercitrin) xanthones and tannins. HP has recently

Address for Correspondence/Yazışma Adresi: Fadime Kahyaoğlu MSc,

Avrasya University Vocational School of Health Services, Department of Pathology Laboratory Techniques, Trabzon, Turkey

Phone: +90 5363633485 E-mail: fadimekahyaoglu@hotmail.com ORCID ID: orcid.org/0000-0002-5149-8051

Received/Geliș Tarihi: 06.02.2018 Accepted/Kabul Tarihi: 27.03.2018

${ }^{\oplus}$ Copyright 2018 by Turkish Society of Obstetrics and Gynecology

Turkish Journal of Obstetrics and Gynecology published by Galenos Publishing House 
received interest as a herbal product that has anti-inflammatory and antiviral properties, and is effective for wound healing, inflammatory bowel disease, and depression ${ }^{(1,5)}$. Depression is an important disease that affects the whole society at all ages and the incidence in pregnancy period is reported as $18-19 \%{ }^{(6)}$. It is known that the antidepressant activity of the plant (at doses of $900 \mathrm{mg} / \mathrm{kg}$ ) is related to hypericin and its derivatives. It can also be abused for believing well-being and well-feeling (Biggs et. al. ${ }^{(7)}$ 2017). There are no well-established controlled clinical trials evaluating the safety of HP use, even in the European Medical Agency Guidelines (EMA/HMPC/244315/2016, 2018), ${ }^{(8)}$ for patients who want to become pregnant or are pregnant while under HP treatment. The view that "herbal products are less harmful" is misleading; their use without rigorous research can also bring about important health issues. Therefore, we aimed to investigate the embriotoxic/teratogenic effects of HP according to fetal clinical, morphologic, and histologic findings.

\section{Materials and Methods}

Fifty-four 4-5-month-old female Wistar rats were obtained from the experimental animal center of our university and all tests were conducted according to the principles and guidelines of the university animal ethical committee's approval (HADYEK 2015/67). HP was obtained from local pharmacy store (St. John's Wort Herb Extract/SOLGAR İstanbul, Turkey). On the study day, the rats were randomly assigned to three groups of 18 animals. Control group: This group of rats has been taken with water freely and served as control.

Low dose HP group: $100 \mathrm{mg} / \mathrm{kg}$ HP given to the rats with drinking water, which was available ad libitum.

High dose HP group: $300 \mathrm{mg} / \mathrm{kg}$ HP given to the rats with drinking water, which was available ad libitum.

HP treatment was started one week before mating, similar to the Gregoretti et al. ${ }^{(9)}$ study, and continued till delivery. The rats were weighed every Monday to adjust the HP doses. The calculated amount of HP was mixed with drinking water every morning, making sure that there was no remnants from the previous day. The suggested daily dose of HP is $900 \mathrm{mg}$ (or $15 \mathrm{mg} / \mathrm{kg}$ per day for a $60-\mathrm{kg}$ person) for humans; Rayburn et al. ${ }^{(10)}$, calculated the rodent dose as $180 \mathrm{mg} / \mathrm{kg}$ per day in their study. Gregoretti et al. ${ }^{(9)}$ calculated the surface area of rats and determined the dose as 100 and $1000 \mathrm{mg} / \mathrm{kg}$ for rats. Given that our aim was not to work with high doses, rather just to mimic real life, considering Rayburn et al.'s ${ }^{(10)}$ study, we administered two different doses of HP treatment to gain a better understanding of dose effect and decided upon $100 \mathrm{mg} / \mathrm{kg}$ and $300 \mathrm{mg} / \mathrm{kg}$.

Maternal rats were sacrificed undergeneral anesthesia of ketamine and xylazine (50 and $5 \mathrm{mg} / \mathrm{kg}$, respectively) immediately after delivery. Obtained offspring were decerebrated, then morphologically examined and fixed in formalin solution. The obtained preparations were evaluated using hematoxylin and eosin and immunohistochemical staining.

\section{Statistical Analysis}

All biologic parameters were assessed using the Mann-Whitney U test (IBM SPSS Statistics for Windows; Version 19.0, IBM Corp., NY, US).

\section{Results}

\section{Morphologic-clinical assessment}

The number of fetuses was six in the low-dose $(100 \mathrm{mg} / \mathrm{kg})$ group, three in the high-dose $(300 \mathrm{mg} / \mathrm{kg})$ group, and eight in the control group; the pregnancy rate decreased in a dosedependent manner (Table 1). In the high-dose treatment group there was also a tendency for delayed delivery; more offspring were born on day 22 (Table 1). The total number of pups also decreased (Table 2); the difference was statistically significant $(\mathrm{p}=0.014)$. No structural extremity anomalies, facial anomalies or differences of eye openness were observed in any pups. Regarding the weight and length of the fetuses, there was a $19.9 \%$ reduction in the weight of the fetuses of the low-dose group, and an $8.4 \%$ reduction in the high-dose group (Table 3 ).

\section{Hematoxylin and eosin assessment}

Our histologic evaluation showed an inflammatory reaction in the liver of the offspring of both treated groups. Additionally, focal necrosis was detected in each lobe, deteriorating cell layout at $300 \mathrm{mg} / \mathrm{kg}$. Hydropic and vacuolar degeneration was also observed in the fetuses of rats with high-dose HP treatment. No fatty change of the liver was found. Hematopoiesis was not disrupted and continued in the fetal period.

Table 1. Morphologic evaluations of the control group and treated groups

\begin{tabular}{|c|c|c|c|}
\hline $\begin{array}{l}\text { Delivery day/the number of } \\
\text { pregnancy }\end{array}$ & Day 21 & Day 22 & $\begin{array}{l}\text { Macroscopic } \\
\text { anomalies }\end{array}$ \\
\hline Control group & 4 rats & 4 rats & No \\
\hline 100 mg/kg HP group & 4 rats & 2 rats & No \\
\hline 300 mg/kg HP group & 1 rats & 2 rats & No \\
\hline
\end{tabular}

Table 2. Number of pups in all groups

\begin{tabular}{|c|c|c|}
\hline $\begin{array}{l}\text { Study groups/the } \\
\text { number of pups born }\end{array}$ & Day 21 & Day 22 \\
\hline Control group & $\begin{array}{l}1^{\text {st }} \text { birth: } 19 \text { pups } \\
2^{\text {nd }} \text { birth: } 10 \text { pups } \\
3^{\text {rd }} \text { birth: } 12 \text { pups } \\
4^{\text {th }} \text { birth: } 10 \text { pups }\end{array}$ & $\begin{array}{l}1^{\text {st }} \text { birth: } 15 \text { pups } \\
2^{\text {nd }} \text { birth: } 14 \text { pups } \\
3^{\text {rd }} \text { birth: } 13 \text { pups } \\
4^{\text {th }} \text { birth: } 10 \text { pups }\end{array}$ \\
\hline Low-dose HP group & $\begin{array}{l}1^{\text {st }} \text { birth: } 12 \text { pups } \\
2^{\text {nd }} \text { birth: } 16 \text { pups } \\
3^{\text {rd }} \text { birth: } 8 \text { pups } \\
4^{\text {th }} \text { birth: } 14 \text { pups }\end{array}$ & $\begin{array}{l}1^{\text {st }} \text { birth: } 12 \text { pups } \\
2^{\text {nd }} \text { birth: } 12 \text { pups }\end{array}$ \\
\hline High-dose HP group & $1^{\text {st }}$ birth: 16 pups & $\begin{array}{l}1^{\text {st }} \text { birth: } 11 \text { pups } \\
2^{\text {nd }} \text { birth: } 11 \text { pups }\end{array}$ \\
\hline
\end{tabular}


In the kidney tissues, we found that the diameter of glomeruli was decreased, the Bowman capsule distance was absent and intense congestion was observed equally in the offspring of both plant-treated groups. Additionally, hydropic and hyaline degeneration was seen in kidney tubules (Figure 1).

\section{Immunohistochemical assessment}

Inducible nitric oxide synthase (iNOS) antibody staining of the tissues was used to determine oxidative stress parameters. Levels of damage were determined in fetal liver tissues of rats as low $(++)$ and high $(+++)$. When evaluating oxidative damage in

Table 3. Morphologic evaluations of the offspring in all groups

$\begin{array}{llll}\begin{array}{l}\text { Study groups/ } \\ \text { morphologic parameters }\end{array} & \begin{array}{l}\text { Average } \\ \text { length }(\mathrm{cm})\end{array} & \begin{array}{l}\text { Tail length } \\ (\mathrm{cm})\end{array} & \text { Weight }(\mathrm{g}) \\ \text { Control group } & 3.89 & 1.34 & 6.59 \\ \text { Low-dose HP group } & 3.86 & 1.5 & 5.28 \\ \text { High-dose HP group } & 3.86 & 1.34 & 6.04 \\ \text { HP: Hypericum perforatum } & & & \end{array}$

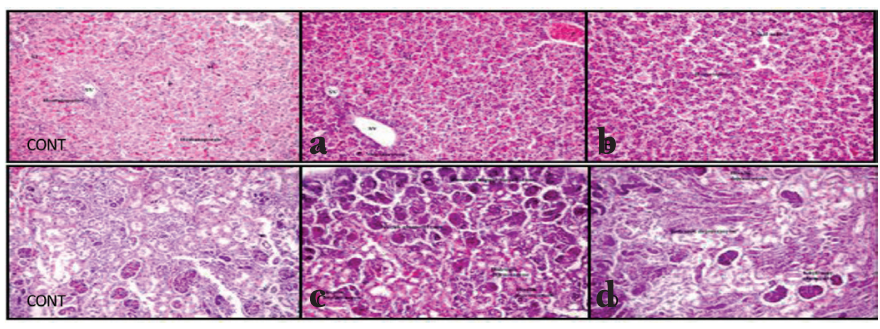

Figure 1. Hematoxylin and eosin (X20) staining of control group and treated individuals. a) Liver tissue of rat embryo treated with low dose $100 \mathrm{mg} / \mathrm{kg}$ Hypericum perforatum (HP) treatment, b) Liver tissue of rat embryo treated with high-dose $300 \mathrm{mg} / \mathrm{kg}$ HP treatment, c) Kidney tissue of rat embryo treated with low dose $100 \mathrm{mg} / \mathrm{kg}$ HP treatment, d) Renal tissue of rat embryo treated with high-dose $300 \mathrm{mg} / \mathrm{kg}$ HP treatment

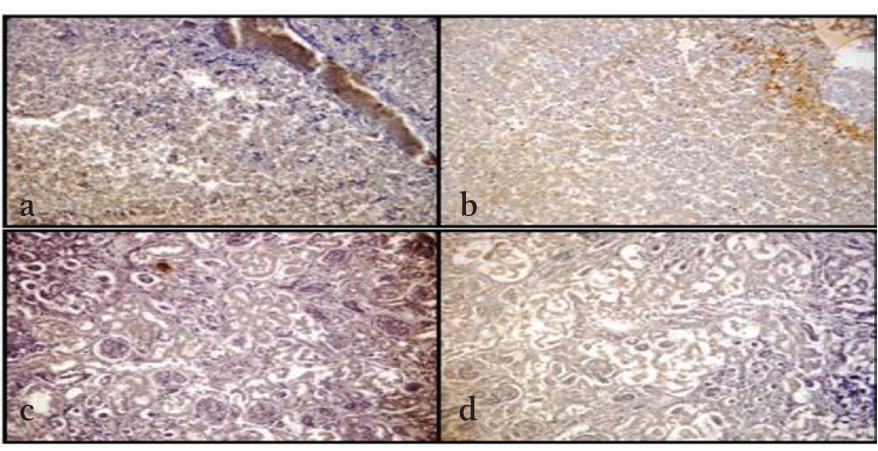

Figure 2. Inducible isoform immunohistochemistry (X20) staining for treated individuals. a) Liver tissue of rat embryo treated with low dose $100 \mathrm{mg} / \mathrm{kg}$ Hypericum perforatum (HP) treatment, b) Liver tissue of rat embryo treated with high-dose $300 \mathrm{mg} / \mathrm{kg}$ HP treatment, c) Kidney tissue of rat embryo treated with low dose $100 \mathrm{mg} / \mathrm{kg}$ HP treatment, d) Renal tissue of rat embryo treated with high-dose $300 \mathrm{mg} / \mathrm{kg}$ HP treatment kidney tissues of the fetuses, the damage was determined as low $(++)$ and high (+++) (Figure 2).

\section{Discussion}

As in all herbal medicines, HP is considered innocuous and widely used against depression, and even women who are pregnant or lactating are also exposed to $\mathrm{HP}^{(6)}$. However, the effects of its use on gestation have yet to be clarified ${ }^{(8)}$.

Limited numbers of experimental studies of HP are available; different results have been obtained in animal experiments. In one study, $36 \mathrm{mg} / \mathrm{kg} /$ day was given to 15 rats in the organogenesis period (days 9-15), they were sacrificed on the $21^{\text {st }}$ day of pregnancy, and the number of fetuses and resorption rates were calculated during a laparotomy. The size of the fetuses was also measured and the result of the clinical examination showed that HP was not embryo toxic. Given that the fluid and food intake and weight change of the animals were the same as those of the control rats, HP was not found as toxic for the mothers either, but a histologic examination was not included in this study ${ }^{(11)}$. That study is similar to our work in some direction; no macroscopic difference was determined in the offspring. However, unlike our study, we also found that the rate of conception decreased dose-dependently by giving HP one week before mating. Additionally, the high-dose treatment groups' delivery day tended to delay. Previously, the Calcium channel antagonist properties of HP were shown on rat aorta; in this case, HP might also behave as a dose-dependent tocolytic agent ${ }^{(4)}$. On the other hand, the conception rate and the number of pups also decreased. This point needs further investigation regarding the ovarian capacity effect of HP. At some point, 100 $\mathrm{mg} / \mathrm{kg}$ or $300 \mathrm{mg} / \mathrm{kg}$ HP was enough to cause a detrimental effect on the gestation rate, gestation duration, and offspring number. Regarding the weight and length of the fetuses, there was a $19.9 \%$ and $8.4 \%$ reduction in the weight of the fetuses. Only the findings of Rayburn et al., ${ }^{(12)}$ support our findings; they also found birth weights of male mice were less than controls. Two of Rayburn et al.'s ${ }^{(12)}$ studies were on cognitivebehavioral changes and the authors reported its safety with regards cognitive functions, but a toxicity and histopathologic evaluation on pups tissues were not performed ${ }^{(10)}$. In a study, HP was started on the $3^{\text {rd }}$ gestational day and ended on the $21^{\text {st }}$ postnatal day. The authors found no effect on the duration of gestation or offspring body weight alteration, but they described some treated groups weighed significantly less than the controls on the $56^{\text {th }}$ postnatal day. As a result, HP was found to affect the development of mice without seriously affecting their neurobehavioral development ${ }^{(13)}$. Chan et al. ${ }^{(14)}$ concluded that giving the active component, hypericin (14.2 and 142.0 $\mathrm{ng} / \mathrm{mL}$ ), to embryo cultures was teratogenic on rat embryos.

In another study, HP was administered via gavage to rats at two different doses, $100 \mathrm{mg} / \mathrm{kg}$ and $1000 \mathrm{mg} / \mathrm{kg}$, starting 2 weeks prior to application and continued till day 21 of lactation ${ }^{(9)}$. When the mothers took $100 \mathrm{mg} / \mathrm{kg} \mathrm{HP}$, hepatocyte cell vacuolization 
was determined in the liver of fetuses and $1000 \mathrm{mg} / \mathrm{kg}$ treatment increased hepatocellular damage with hyaline degeneration, lobular fibrosis, and disorganization of hepatocytes arrays ${ }^{(9)}$. Their study supports our histologic findings in a great measure. HP showed an inflammatory reaction in the fetal liver tissue in both treated groups. Additionally, $300 \mathrm{mg}$ developed focal necrosis, and hydropic and vacuolar degeneration of fetal liver tissues. Hematopoiesis was not disrupted and continued in the fetal period, and no fatty change in the liver was seen. The same paper also proved that glomerular size was reduced, the Bowman capsule was absent, and that hyaline tubular degeneration developed. Interestingly, these findings were also found in the offspring, even when they were only exposed to HP during the 21-day lactation period ${ }^{(9)}$. Similar to that study, we determined that the diameter of glomeruli was decreased, the Bowman capsule distance was absent, and intense congestion was observed equally in the offspring of both plant-treated groups. Additionally, we determined hydropic and hyaline degeneration in kidney tubules. The structural changes that we detected in the liver and kidney were probably due to free oxygen radical generation and consequently to oxidative damage. There are three different NOS enzyme isoforms: neuronal NOS (nNOS), endothelial NOS (eNOS), and iNOS, which are stimulated by certain cytokines. In pathologic conditions, macrophages and smooth muscle cells in hepatocytes induce iNOS and produce nitric oxide (NO). Excess production of $\mathrm{NO}$ results in oxidative tissue damage. Immunohistochemically, we applied iNOS antibody staining to detect the presence of oxidative damage. We demonstrated that the HP produced oxidative damage in the liver and kidney tissues of the fetuses.

\section{Study Limitations}

The limitation of this study is HP effects on the other organs such as neuro-development could not been detected, further studies should be performed about safety of HP.

\section{Conclusion}

HP exposure before conception diminished the pregnancy rate and decreased the fetal number; during pregnancy it tented to increase the duration of gestation, and deteriorated fetal development as determined through body weight. It also damaged liver and kidney tissues, most probably due to oxidative stress at both doses, as supported with iNOS antibody staining. Therefore, HP should not be recommended to any women who want to be pregnant or who are pregnant, because it can be harmful for both fetal and maternal health.

\section{Ethics}

Ethics Committee Approval: Adnan Menderes University for Animal Experiments (HADYEK 2015/67).

Informed Consent: Consent form was filled out by all participants.

Peer-review: External and internal peer-reviewed.

\section{Authorship Contributions}

Surgical and Medical Practices: F.K., B.D., Concept: B.D., A.G., Design: F.K., B.D., Data Collection or Processing: F.K., B.D., A.G., Analysis or Interpretation: F.K., B.D., A.G., Literature Search: F.K., B.D., Writing: F.K., B.D.

Conflict of Interest: No conflict of interest was declared by the authors.

Financial Disclosure: This study was supported by the grant (TPF 15063) of Adnan Menderes University.

\section{References}

1. Kaçar O, Azkan N. Bursa'da Doğal Florada Bulunan Sarı Kantaron (Hypericum perforatum L.) Populasyonlarında Farklı Yüksekliklerin Hiperisin Oranı Üzerine Etkisinin Belirlenmesi. U. Ü. Ziraat Fakültesi Dergisi 2005;19:77-89.

2. Ekren S, Sönmez Ç, Bayram E. Sarı Kantaron (Hypericum perforatum L.) Klonlarında Bazı Tarımsal ve Kalite Özelliklerinin Belirlenmesi. Journal of Agricultural Sciences 2010;6:225-34.

3. Hışl Y, Şahin F, Omay SB. Kantaronun (Hypericum perforatum L.) Bileşimi ve Tibbi Önemi. International Journal of Hematology and Oncology 2005; 15:212-8.

4. Tugrul I, Demirci B, Demir O, Dost T, Birincioglu M. The effect of Hypericum Perforatum on isolated rat aorta. Pharm Bio 12011;49:879-83.

5. No authors listed. Monograph. Hypericum perforatum. Altern Med Rev 2004;9:318-25.

6. Deligiannidis KM, Freeman MP. Complemantary and alternative medicine therapies for perinatal depression. Best Pract Res Clin Obstet Gynaecol 2014;28:85-95.

7. Biggs JM, Morgan JA, Lardieri AB, Kishk OA, Klein-Schwartz W. Abuse and misuse of selected dietary supplements among adolescents: A look at poison center data. J Pediatr Pharmacol Ther 2017;22:385-93

8. Committee on herbal medicinal products (HMPC) draft. EMA/ HMPC/244315/2016. Assessment report on Hypericum perforatum L., herba. European Medicines Agency, Science Evaluation Medicines Health for Human Use London; 2018:1-144.

9. Gregoretti B, Stebel M, Candussio C, Crivellato E, Bartoli F, Decorti G. Toxicity of Hypericum perforatum (St. John's wort) administered during pregnancy and lactation in rats. Toxicol Appl Pharmacol 2004;200:201-5.

10. Rayburn WF, Gonzalez CL, Christensen HD, Harkins TL, Kupiec TC. Impact of Hypericum (St.-John's-wort) given prenatally on cognition of mice offspring. Neurotoxicol Teratol 2001;23:629-37.

11. Borges LV, do Carmo Cancino JC, Peters VM, Las Casas L, de Oliveira Guerra M. Development of pregnancy in rats treated with hypericum perforatum. Phytother Res 2005;19:885-7.

12. Rayburn WF, Christensen HD, Gonzalez CL. Effect of antenatal exposure to Saint John's wort (Hypericum) on neurobehavior of developing mice. Am J Obstet Gynecol 2000;183:1225-31.

13. Cada AM, Hansen DK, LaBorde JB, Ferguson SA. Minimal effects from developmental exposure to St. John's wort (Hypericum perforatum) in Sprague-Dawley rats. Nutr Neurosci 2001;4:135-41.

14. Chan LY, Chiu PY, Lau TK. A study of hypericin-induced teratogenicity during organogenesis using a whole rat embryo culture model. Fertil Steril 2001;76:1073-4. 